\title{
Вплив вправ з м'ячем на координаційні здібності юних спортсменів 8-9 років, які займаються тенісом настільним
}

\author{
Ірина Помещикова \\ Ярославна Асєєва \\ Юрій Чуча
}

Харківська державна академія фізичної культури, Харків, Україна

\section{Мета: розробка підходів щодо покращення координаційних здібностей юних спортсменів у тенісі настільному} під впливом спеціально підібраних вправ із тенісним м'ячем.

Матеріал і методи: у дослідженні приймали участь дві групи юних вихованців дитячо-юнацької спортивної школи №11 м. Харкова у віці 8-9 років у загальній кількості 24 осіб (контрольна група, n=12, експериментальна група, $n=12)$. Для визначення показників прояву координаційних здібностей використовувались тести, рекомендовані навчальною програмою для дитячо-юнацьких спортивних шкіл з настільного тенісу. Педагогічний експеримент тривав 3 місяці та полягав у впровадженні в практику експериментальної групи спеціально підібраних вправ.

Результати: введення у навчально-тренувальний процес експериментальної групи вихованців 8-9 років з настільного тенісу вправ з тенісним м'ячем, спрямованих на розвиток координаційних здібностей, було виявлено достовірне покращення показників тестових вправ: у набиванні тенісного м'яча на ракетці за 1 хв., на внутрішній і на зовнішній стороні ракетки та чергуючи сторону ракетки, біг боком навколо столу, біг по вісімці $(p<0,05)$. В тестах підкидання і ловля тенісного м'яча двома руками за 30 с, перенесення м'ячів, під час пересування у 3-х метровій зоні вірогідної відмінності виявлено не було ( $p>0,05)$.

Висновки: покращення прояву показників координаційних здібностей у дітей 8-9 років експериментальної групи, які займаються настільним тенісом після впровадження спеціально підібраної системи вправ із тенісним м'ячем становили: у тесті «Набивання тенісного м'яча на ракетці за 1 хв. на внутрішній стороні ракетки» - 25,3 \%, «Набивання тенісного м'яча на ракетці за 1 хв. на зовнішній стороні ракетки» - 27,3 \%, «Набивання тенісного м'яча на ракетці за 1 хв. на внутрішній і зовнішній стороні ракетки по черзі» - 39,0\%, «Підкидання і ловля тенісного м'яча двома руками не вище голови за 30 c» - 5,5 \%, «Біг боком навколо столу» - 5, 8 \%, «Біг по вісімці» - 2,5 \%, «Перенесення м'ячів, під час пересування у 3-х метровій зоні» - 2, 7 \%

Ключові слова: теніс настільний; координаційні здібності; вправи із м'ячами; вправи із ракеткою.

\section{Вступ}

Координаційні здібності $€$ складною, комплексною психофізичною якістю. Вони пов'язані з функцією управління, а це означає, що головну роль у прояві цієї якості відіграє центральна нервова система. Цією обставиною обумовлений і той факт, що координаційні здібності є більш різносторонньою, гнучкою і універсальною фізичною якістю в порівнянні з іншими. Р. Худєц відносить настільний теніс до складно координаційних видів спорту. Автор відзначає, що дії гравця залежать від ряду факторів: швидкості польоту тенісної кульки, швидкості удару і часу необхідного для прийняття рішення при атаці суперника [16].

Процес оволодіння будь-якими руховими діями відбувається значно успішніше, якщо спортсмен має не лише міцні й швидкі м'язи, гнучке тіло, але й високо розвинуті здібності до керування власними рухами, його основними характеристиками. Високий рівень розвитку координаційних здібностей - основна база оволодіння новими, складнішими видами рухових дій у спортивній діяльності [15].
Високий рівень розвитку координаційних здібностей особливо важливий для дітей на етапі початкової підготовки. Так, як розвинена координація дозволяє дитині швидко освоювати нові рухові дії, бути рухливим, швидко реагувати на мінливу обстановку. Розвиваючи координацію юних спортсменів можна закласти важливу базу для формування складних рухових умінь і навичок, а також впевненість в собі, на тлі сформованих рухових умінь.

Для настільного тенісу важливе значення у досягненні високих спортивних результатів та у володінні ефективної технікою мають такі координаційні здібності, як здатність до диференціації м'язових зусиль, почуття ритму, швидке перестроювання рухової діяльності, статокінетична стійкість і здатність до узгодження рухів.

Коломійцева О., Радченко Я. відзначають, що і сам настільний теніс $є$ засобом розвитку координаційних здібностей. Це пояснюється виконанням великої кількості подач та різноманітних ударів по м'ячу під час матчу [5]. Аналогічної думки і Глоба Т.А., яка з метою розвитку координаційних здібностей пропонує використовувати у студентів у процесі занять фізичним вихованням настільний теніс [2].
Слобожанський науково-спортивний вісник, № 1(81), С. 71-78, doi:10.15391/snsv.2021-1.010 
Роман Файчак, Сергій Попель, Іван Файчак по закінченню педагогічного експерименту, який тривав 8 місяців упродовж навчального року, де студенти-тенісисти використовували запропоновану методику розвитку окремих складових координаційних здібностей, побудованої на блоках вправ, які виконувалися у процесі розминки до тренування та у самостійному опрацюванні, покращили прояв координаційних здібностей тих, хто займався [15]. Маленюк Т.В. для студентів-тенісистів запропонувала експериментальну методику розвитку координаційних здібностей із застосуванням блоків вправ на удосконалення здібності до управління тимчасовими просторовими і силовими параметрами руху, для удосконалення здібності до орієнтування у просторі, відчуття ритму, відчуття м'яча. Основні положення авторської методики удосконалення координаційних здібностей: метод тренування - повторний; тривалість вправ - короткочасна; інтенсивність виконання вправи - максимальна або субмаксимальна; тривалість інтервалів відпочинку - повне відновлення; характер інтервалів відпочинку - пасивний або змішаний; кількість повторень - до стомлення. Педагогічний експеримент тривав впродовж навчального року. По закінченню експерименту автор відзначає достовірне покращення результату за показниками орієнтування у просторі і точності рухів $(p<0,05)[7]$.

У попередніх дослідженнях нами були визначені показники технічної [1] та спеціальної фізичної підготовленості спортсменів в групі базової підготовки тенісу настільного [18]. Було розглянуто взаємозв'язок психофізіологічних показників та показників технічної підготовленості спортсменів у настільному тенісі.

Наші попередні дослідження були спрямовані на адаптацію молоді із порушеннями ОРА через розвиток у них координаційних здібностей [23, 24]. Вивчалися показники координаційних здібностей школярів Китайської республіки [22]. Було розроблено і експериментально підтверджено методику удосконалення технічної підготовленості юних гандболісток на основі використання координаційних вправ на швидкісний координаційній драбині [20]. Аналізувався стан координаційних здібностей баскетболістів студентської команди [11], та перевірялася методика його підвищення завдяки використанню спеціально підібраних вправ з баскетбольним м'ячем [10]. Результати нашіх попередніх досліджень дозволили встановити рівень показників просторової орієнтації баскетболисток у віці 14 років [21]. Досліджувалися показники рівноваги баскетболістів 12 років, та встановлено значний вплив вправ на балансувальній полусфері на статокінетичну стійкість юних гравців [12]. Отримані результати є деяким обгрунтуванням наших підходів для даного дослідження.

За результатами проведених досліджень можемо припустити, що використання спеціально підібраних вправ із тенісним м'ячем, тенісною ракеткою, вправ з елементами технічних прийомів настільного тенісу може підвищити рівень координаційних рухових дій спортсменів.

Зв'язок дослідження з науковими програмами, планами, темами. Дослідження проводилося відповідно теми плану НДР Харківської державної академії фізичної культури «Удосконалення навчально-тренувального процесу в спортивних іграх» на 2019-2023 рр.

Мета дослідження - розробка підходів щодо покращення координаційних здібностей юних спортсменів у тенісі настільному під впливом спеціально підібраних вправ із тенісним м'ячем.

\section{Завдання дослідження:}

1. Провести аналіз наукової та методичної літератури стосовно обраної теми.

2. Визначити рівень розвитку окремих координаційних здібностей гравців 8-9 років, які займаються тенісом настільним.

3. Підібрати та експериментально довести ефективність застосування спеціально підібраних вправ на розвиток окремих координаційних здібностей тенісистів.

\section{Матеріал і методи дослідження}

У дослідженні приймали участь дві групи юних вихованців дитячо-юнацької спортивної школи №11 м. Харкова у віці 8-9 років у загальній кількості 24 осіб (контрольна група, n=12, експериментальна група, $\mathrm{n}=12)$. Обидві групи початкового навчання другого року. Для визначення показників прояву координаційних здібностей використовувались тести, рекомендовані навчальною програмою для дитячо-юнацьких спортивних шкіл з настільного тенісу [8]. Педагогічний експеримент тривав 3 місяці та полягав у впровадженні в практику експериментальної групи спеціально підібраних вправ. Це вправи, в яких виконувалися кидки тенісного м'яча у стіну (кидки у стіну із ловлею після оплеску за спиною, обертання на $360^{\circ}$, присідання після одного удару об підлогу); вправи із підкиданням тенісного м'яча рукою і ловіння або рукою або пластиковим стаканчиком (перекладаючи стаканчик із руки у руку, виконуючи декілька кидків поспіль) при цьому намагаючись не сходити із місця; набивання тенісного м'яча ракеткою, міняючи сторону ракетки, правою та лівою рукою, як на місці, так і в русі (рухаючись обличчя та спиною уперед, приставним кроком у вправо, у ліво); кидки тенісного м'яча на точність у квадрати намальовані на тенісному столі, та удари на точність ракеткою у розмітку; удари, накати з різних кутів столу у задані сектори; удари різними способами із зміно тенісного столу (два столи стояли поряд), тощо (рис. 1). Запропоновані вправи застосовувались на кожному тренувальному занятті у підготовчій і основній частині. У підготовчій частині - загальнорозвивальні вправи, в основній частині - вправи, пов'язані із прийомами техніки. Загальна кількість тренувальних занять у тиждень контрольної та експериментальної групи дорівнювала чотирьом по 90 хвилин.

Для аналізу отриманої інформації використовувався пакет програми Microsoft Excel, достовірність у розбіжностях встановлювалась на базі розрахунку критерію Ст'юдента, при р<0,05.

\section{Результати дослідження}

На початку педагогічного експерименту контрольна і експериментальна групи вірогідно не відрізнялися одна від одної за усіма показниками тестування прояву координаційних здібностей (табл. 1).

Після проведення експерименту порівнюючи результати тестування в експериментальній групі було виявлено достовірне покращення результатів в тестах: набивання тенісного м'яча на ракетці за 1 хв., на внутрішній і на зовнішній стороні ракетки та чергуючи сторону ракетки, біг боком навколо столу, біг по вісімці $(\mathrm{p}<0,05)$. В тестах підкидання і ловля тенісного м'яча двома ру- 


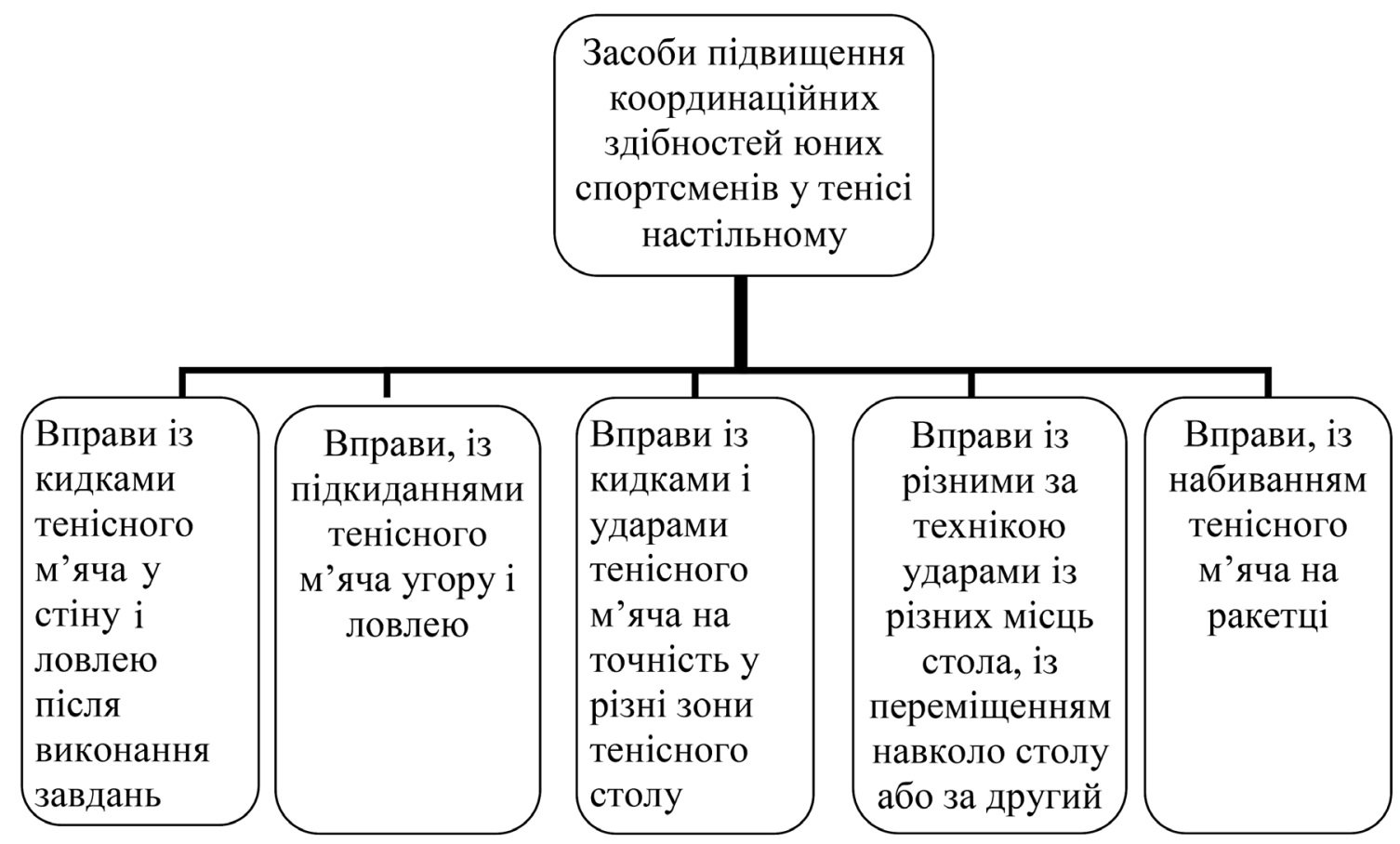

Рис. 1.

Засоби підвищення координаційних здібностей спортсменів 8-9 років у настільному тенісі

\begin{tabular}{|c|c|c|c|c|c|}
\hline \multicolumn{2}{|c|}{ Тести } & \multicolumn{4}{|c|}{ Показники $\bar{X} \pm \mathrm{m}$} \\
\hline & & $\mathrm{E} \Gamma(n=12)$ & $\mathrm{K} \Gamma(\mathrm{n}=12)$ & $\mathrm{t}$ & $\mathrm{p}$ \\
\hline \multirow{3}{*}{$\begin{array}{c}\text { Набивання тенісного } \\
\text { м'яча на ракетці за } 1 \text { хв. } \\
\text { (рази) }\end{array}$} & $\begin{array}{l}\text { на внутрішній } \\
\text { стороні ракетки }\end{array}$ & $25,7 \pm 2,3$ & $25,4 \pm 2,1$ & 0,10 & $>0,05$ \\
\hline & $\begin{array}{l}\text { на зовнішній } \\
\text { стороні ракетки }\end{array}$ & $12,8 \pm 1,1$ & $12,1 \pm 1,7$ & 0,35 & $>0,05$ \\
\hline & $\begin{array}{c}\text { на внутрішній і } \\
\text { зовнішній стороні } \\
\text { ракетки по черзі }\end{array}$ & $10,5 \pm 1,5$ & $9,9 \pm 1,9$ & 0,25 & $>0,05$ \\
\hline \multicolumn{2}{|c|}{$\begin{array}{c}\text { Підкидання і ловля тенісного м'яча двома } \\
\text { руками не вище голови за } 30 \text { с (рази) }\end{array}$} & $9,1 \pm 0,2$ & $9,6 \pm 0,3$ & 1,39 & $>0,05$ \\
\hline \multicolumn{2}{|c|}{ Біг боком навколо столу (c) } & $29,2 \pm 0,6$ & $29,1 \pm 0,7$ & 0,11 & $>0,05$ \\
\hline \multicolumn{2}{|c|}{ Біг по вісімці (c) } & $36,3 \pm 0,5$ & $37,0 \pm 0,6$ & 0,90 & $>0,05$ \\
\hline \multicolumn{2}{|c|}{$\begin{array}{c}\text { Перенесення м’ячів, під час пересування у 3-х } \\
\text { метровій зоні (c) }\end{array}$} & $48,4 \pm 0,3$ & $48,9 \pm 0,4$ & 1,00 & $>0,05$ \\
\hline
\end{tabular}

Таблиця 1

Порівняння показників координаційних здібностей тенісистів 8-9 років експериментальної і контрольної груп до педагогічного експерименту 


\section{Таблиця 2 \\ Показники прояву координаційних здібностей тенісистів 8-9 років експериментальної групи до і після педагогічного експерименту}

\begin{tabular}{|c|c|c|c|c|c|}
\hline \multirow{2}{*}{\multicolumn{2}{|c|}{ Тести }} & \multicolumn{4}{|c|}{ Показники $\bar{X} \pm \mathrm{m}$} \\
\hline & & \multirow{2}{*}{$\begin{array}{c}\text { До } \\
\text { експерименту } \\
(\mathrm{n}=12)\end{array}$} & \multirow{2}{*}{$\begin{array}{c}\text { Після } \\
\text { експерименту } \\
(n=12)\end{array}$} & \multirow{2}{*}{$\begin{array}{c}\mathrm{t} \\
2,09\end{array}$} & \multirow{2}{*}{$\begin{array}{c}\mathrm{p} \\
<0,05\end{array}$} \\
\hline \multirow{3}{*}{$\begin{array}{c}\text { Набивання } \\
\text { тенісного м'яча } \\
\text { на ракетці за } 1 \\
\text { хв. (рази) }\end{array}$} & $\begin{array}{l}\text { на внутрішній } \\
\text { стороні ракетки }\end{array}$ & & & & \\
\hline & $\begin{array}{c}\text { на зовнішній } \\
\text { стороні ракетки }\end{array}$ & $12,8 \pm 1,1$ & $16,3 \pm 1,2$ & 2,15 & $<0,05$ \\
\hline & $\begin{array}{l}\text { на внутрішній і } \\
\text { зовнішній } \\
\text { стороні ракетки } \\
\text { по черзі }\end{array}$ & $10,5 \pm 1,5$ & $14,6 \pm 1,3$ & 2,07 & $<0,05$ \\
\hline \multicolumn{2}{|c|}{$\begin{array}{c}\text { Підкидання і ловля тенісного м'яча } \\
\text { двома руками не вище голови за } \\
30 \text { с (рази) }\end{array}$} & $9,1 \pm 0,2$ & $9,6 \pm 0,3$ & 1,39 & $>0,05$ \\
\hline \multicolumn{2}{|c|}{ Біг боком навколо столу (c) } & $29,2 \pm 0,6$ & $27,5 \pm 0,5$ & 2,18 & $<0,05$ \\
\hline \multicolumn{2}{|c|}{ Біг по вісімці (c) } & $36,3 \pm 0,5$ & $35,4 \pm 0,7$ & 2,09 & $<0,05$ \\
\hline \multicolumn{2}{|c|}{$\begin{array}{c}\text { Перенесення м’ячів, під час } \\
\text { пересування у 3-х метровій зоні (c) }\end{array}$} & $48,4 \pm 0,3$ & $47,1 \pm 0,7$ & 1,79 & $>0,05$ \\
\hline
\end{tabular}

ками за 30 с, перенесення м'ячів, під час пересування у 3-х метровій зоні вірогідної відмінності виявлено не було ( $>>0,05)$. Результати наведено в таблиці 2.

Покращення прояву показників координаційних здібностей у дітей 8-9 років експериментальної групи, які займаються настільним тенісом становили: у тесті «Набивання тенісного м'яча на ракетці за 1 хв. на внутрішній стороні ракетки» - на 25,3 \%, «Набивання тенісного м'яча на ракетці за 1 хв. на зовнішній стороні ракетки» - на 27,3 \%, «Набивання тенісного м'яча на ракетці за 1 хв. на внутрішній і зовнішній стороні ракетки по черзі» - на 39,0 \%, «Підкидання і ловля тенісного м'яча двома руками не вище голови за 30 с» - на 5,5\%, «Біг боком навколо столу» - на 5,8 \%, «Біг по вісімці» - на 2,5 \%, «Перенесення м'ячів, під час пересування у 3-х метровій зоні» - на 2,7 \% (рис. 2).

Слід відзначити, що найбільші зміни в показниках прояву координаційних здібностей юних спортсменів експериментальної групи відбулися у тестових вправах, що пов'язані із набиванням тенісного м'яча на ракетці.

\section{Висновки / Дискусія}

Наше дослідження проведено в контексті рекомендацій інших фахівців про необхідність збереження і підвищення рівня фізичної підготовленості юних спортсменів, особливо координаційних здібностей, які є підґрунтям оволодіння прийомами техніки. Автори Черня$\epsilon в$ А. А. і Пайков М. Б. запропонували методику розвитку координаційних здібностей юних спортсменів у настільному тенісі у підготовчому періоді, яка складалася із 3 різних комплексів вправ, які мали визначену направленість. Авторами були підібрані додаткові вправи із тенісною ракеткою і м'ячем та без них, що дозволило за 9 тренувальних мікроциклів значно покращити показники фізичної підготовленості тенісистів $(p<0,05)$ [17]. Дробишом О. С. було підібрано вправи, спрямовані на розвиток координаційних здібностей юних спортсменів 1012 років, які займалися тенісом настільним. Основним методичним прийомом при розвитку координаційних здібностей автором зазначалася наявність ускладнення при виконанні вправ, які реалізовувалися за рахунок 


\section{СЛОБОЖАНСЬКИЙ НАУКОВО-СПОРТИВНИЙ ВІСНИК}

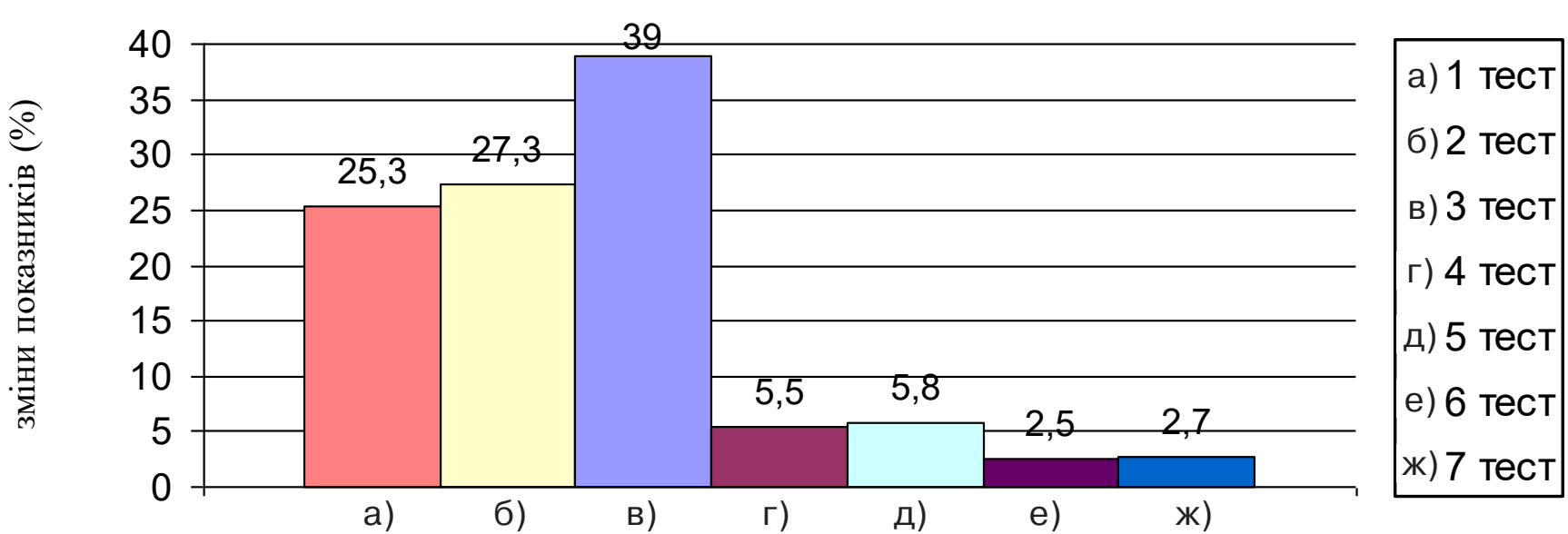

Рис. 2. Якісні показники змін прояву координаційних здібностей тенісистів 8-9 років експериментальної групи після педагогічного експерименту (відсотки):

Тест 1 - Набивання тенісного м'яча на ракетці за 1 хв. на внутрішній стороні ракетки; Тест 2 - Набивання тенісного м'яча на ракетці за 1 хв. на зовнішній стороні ракетки; Тест 3 - Набивання тенісного м'яча на ракетці за 1 хв. на внутрішній і зовнішній стороні ракетки по черзі; Тест 4 - Підкидання і ловля тенісного м'яча двома руками не вище голови за 30 с; Тест 5 - Біг боком навколо столу; Тест 6 - Біг по вісімці; Тест 7 - Перенесення м'ячів, під час пересування у 3-х метровій зоні

збільшення кількості використовуваних предметів. При цьому найбільші прирости показників координаційних здібностей автором відзначені в тесті «Фламінго» на 53,8 \%, в тесті «Човниковий біг 3410 м» на 4 \% [3]. Шиян В. М. відзначав, що у ході дослідження у бадмінтоністів 12-14 років були отримані природно більш значні індивідуальні абсолютні показники координаційних здібностей, порівняно з середньостатистичними значеннями дітей певного віку [19].

Результати наших досліджень продовжують ряд робіт з вивчення і вдосконалення процесу розвитку координаційних здібностей юних спортсменів. Отримані результати нашого дослідження узгоджується з даними інших дослідників $[4,6,15]$. Автори відзначають, що регулярні заняття настільним тенісом, використання вправ із тенісним м'ячем, ракеткою позитивно впливають на прояв координаційних здібностей $[9,13]$.
Отже розроблена нами система підібраних вправ 3 тенісним м'ячем покращила показники прояву координаційних здібностей юних вихованців ДЮСШ 8-9 років експериментальної групи, які займаються тенісом настільний. Це виражається у достовірному покращенні результатів в тестах: набивання тенісного м'яча на ракетці за 1 хв., на внутрішній і на зовнішній стороні ракетки та чергуючи сторону ракетки, біг боком навколо столу, біг по вісімці $(p<0,05)$. Результати наших досліджень дозволяють нам рекомендувати тренерам доповнювати навчально-тренувальний процес груп настільного тенісу системою спеціально підібраних вправ з м'ячем, з метою покращення прояву координаційних здібностей.

Перспективи подальших досліджень ми вбачаємо у науковому дослідженні впливу показників координаційних здібностей на рівень техніко-тактичної підготовленості тенісистів.

Конфлікт інтересів. Автори заявляють, що відсутній конфлікт інтересів, який може сприйматись таким, що може завдати шкоди неупередженості статті.

Джерела фінансування. Ця стаття не отримала фінансової підтримки від державної, громадської або комерційної організації.

\section{Список посилань}

1. Асєєва Я., Шевченко О. (2019), «Взаємозв'язок психофізіологічних показників та технічної підготовленості у спортсменів з настільного тенісу на етапі попередньої базової підготовки», Слобожанський науково-спортивний вісник, № 6К, С. 5-9. DOI: $10.15391 /$ snsv.2019-6.021

2. Глоба Т.А. (2015), «Настільний теніс як засіб розвитку координаційних здібностей студентів у процесі занять фізичним вихованням", Педагогіка формування творчої особистості у вищій і загальноосвітній школах, № 42, С. 87-93.

3. Дробыш А.С. (2016), «Методика развития координационных способностей у спортсменов 10-12 лет, занимающихся настольным теннисом», Туризм и образование: исследования и проекты: материалы Всероссийской, Т. 24, С. $186-189$.

4. Козеток I. (2001), «Формування структури взаємозв'язків рухових якостей і координаційних здібностей у дітей молодшого шкільного віку», Теорія і методика фізичного виховання і спорту, № 1, С. 41-45.

5. Коломійцева О., Радченко Я. (2012), «Настільний теніс як засіб розвитку координаційних здібностей студентів коледжу», Слобожанський науково-спортивний вісник, № 5-1 (32), С. 16-19. 
6. Костенко Е. Г., Лысенко В. В. (2020), «Обработка методологических данных воспитание ловкости у детей», E-Scio, (9 (48)), С. 669-674.

7. Маленюк Т. В., Брояковський О. В. (2020), «Удосконалення загальної фізичної підготовленості студентів на заняттях підвищення спортивної майстерності з настільного тенісу», Проблеми та перспективи розвитку фізичного виховання, спорту і здоров'я людини : матеріали V Всеукр. наук.-практ. конф. (23-24 квітня 2020 р.), Полтава : Сімон, С. 46-52.

8. Настільний теніс. Навчальна програма для дитячо-юнацьких спортивних шкіл, спеціалізованих дитячо-юнацьких шкіл олімпійського резерву, шкіл вищої спортивної майстерності, та спеціалізованих навчальних закладів спортивного профілю / уклад. Гришко Л.Г., Гришко Ю.Ю., Ібраімова М.В. Київ, 2013, 137 с.

9. Окопний А. (2012), «Використання технічних засобів навчання для забезпечення точності рухів гравців у настільний теніс», Молода спортивна наука, ХІ Міжнар. наук.-метод. конф. Донецьк, С. 17-21.

10. Помещикова І., Чуча Н., Чуча Ю., Кудімова, О. (2020). «Зміни показників координаційних здібностей баскетболістів студентської команди під впливом спеціально підібраних вправ з м'ячами», Спортивні ігри, № 2 (16), C. 58-68. https://doi: $10.15391 /$ si.2020-2.06

11. Помещикова І. П., Пащенко Н. О. (2016), «Стан координаційних здібностей баскетболістів студенської команди», Фізична культура, спорт та здоров'я: стан, проблеми та перспективи: матеріали XVI Міжнародної науково-практичної конференції, Харків, грудень 2016 р., С. 193-196.

12. Помещикова І. П., Пащенко Н. О., Ширяєва І. В., Кудімова О. В. (2021), «Зміни показників рівноваги баскетболістів 12 років під впливом вправ на балансувальній півсфері», Спортивні ігри, №. 2 (20), С. 83-91. https://doi: 10.15391/si.2021-2.08

13. Приймаков А. А., Козеток И. И. (2000), «Закономерности развития координационных движений у детей 7-9 лет», Наука в олимпийском спорте, №1, С. 53-59.

14. Прокопенко К. В. (2012), «Характеристика впливу засобів настільного тенісу на рівень фізичної підготовленості учнів молодших класів», Teormв ta Metodika Fmzičnogo Vihovannв, № 6, C. 35-39.

15. Файчак Роман, Попель Сергій, Файчак Іван (2013), «Розвиток координаційних здібностей у спортсменів, що займаються настільним тенісом», Молода спортивна наука України, Т.1, С. 266-269.

16. Худец Р. К. (2005), Настольный теннис. Техника с Владимиром Самсоновым М.: ВистаСпорт. 272 с.

17. Черняев А. А., Пайков М. Б. (2018), «Методика совершенствования координационных способностей у теннисистов 11-12 лет в подготовительном периоде», Современные проблемы науки и образования, № 6, С. 225-225.

18. Шевченко О.О., Асеєва Я.Ф. (2018), «Контроль рівня спеціальної фізичної підготовленості спортсменів в групі базової підготовки тенісу настільного», Спортивні ігри, № 4, С. 60-66.

19. Шиян В.М. (2013), «Особливості розвитку координаційних здібностей бадмінтоністів на етапі попередньої базової підготовки», Слобожанський науково-спортивний вісник, № 5, С. 286-290.

20. Bykova O., Druz V., Pomeshchikova I., Strelnikova E., Strelnikov G., Melnyk A., Shyriaieva I. (2017), «Changes in technical preparedness of 13-14-year-old handball players under the influence of coordination orientation exercises», Journal of Physical Education and Sport, T. 17, № 3, C. 1899-1905. https://doi:10.7752/jpes.2017.03185

21. Pomeschikova I., Yevtushenko A., Yevtushenko I. (2012), «The level of spatial orientation of basketball players aged 14 years», Pedagogics, psychology, medical-biological problems of physical training and sports, № 3, C. 106-109.

22. Pomeshchikova I. P., Zhang Xing Yu, Koval M. (2016), «Level of coordination abilities and physical working capacity of grade 8 female students suzhou wuzhong yingchuu middle school», Education and space (Soul Suzhou China), № 3, C. 83-86.

23. Pomeshchikova I. P., Shevchenko O. O., Yermakova T. S., Paievskyi V. V., Perevoznyk V. I., Koval M. V., Moiseienko O. K. (2016), «Influence of exercises and games with ball on coordination abilities of students with disorders of muscular skeletal apparatus», Journal of Physical Education and Sport, № 16(1), 146-155. https://doi:10.7752/jpes.2016.01024

24. Pomeshchikova I., lermakov S., Bartik P., Shevchenko O., Nosko M., Yermakova T., Nosko Y. (2016), «Influence of exercises and games with ball on vestibular stability of students with muscular-skeletal apparatus disorders», Sport Science, 9 (1), C. $75-83$.

Стаття надійшла до редакції: 27.01.2021 р.

Опубліковано: 22.02.2021 p.

Аннотация. Ирина Помещикова, Ярославна Асеева, Юрий Чуча. Влияние упражнений с мячом на координационные способности юных спортсменов 8-9 лет, занимающихся теннисом настольным. Цель: разработка подходов по улучшению координационных способностей юных спортсменов в теннисе настольном под влиянием специально подобранных упражнений с теннисным мячом. Материал и методы: в исследовании принимали участие две группы юных воспитанников детскоюношеской спортивной школы №11 г. Харькова в возрасте 8-9 лет в общем количестве 24 человек (контрольная группа, $n=12$, экспериментальная группа, $n=12$ ). Для определения показателей проявления координационных способностей использовались тесты, рекомендованные учебной программой для детско-юношеских спортивных школ по настольному теннису. Педагогический эксперимент длился 3 месяца и заключался во внедрении в практику экспериментальной группы специально подобранных упражнений. Результаты: введение в учебно-тренировочный процесс экспериментальной группы воспитанников 8-9 лет по настольному теннису упражнений с теннисными мячами, направленных на развитие координационных способностей, было выявлено достоверное улучшение показателей тестовых упражнений: в набивке теннисного мяча на ракетке за 1 мин., на внутренней и на внешней стороне ракетки и чередуя сторону ракетки, бег боком вокруг стола, бег по восьмерке (p<0,05). В тестах подбрасывание и ловля теннисного мяча двумя руками за 30 c, перенос мячей, во время передвижения в 3-х метровой зоне вероятной различия обнаружено не было ( $>>0,05)$. Выводы: улучшение проявлений показателей координационных способностей у детей 8-9 лет экспериментальной группы, которые занимаются настольным теннисом, после внедрения в учебнотренировочный процесс специально подобранной системы упражнений составили: в тесте «Набивание теннисного мяча на ракетке за 1 мин. на внутренней стороне ракетки»-25,3\%, «Набивание теннисного мяча на ракетке за 1 мин. на внешней стороне ракетки» - 27,3\%, «Набивание теннисного мяча на ракетке за 1 мин. на внутренней и внешней стороне ракетки поочередно» - 39,0\%, «Подбрасывание и ловля теннисного мяча двумя руками не выше головы за 30 с» - 5,5\%, «Бег боком вокруг стола» $-5,8 \%$, «Бег по восьмерке» - 2,5\%, «Перенос мячей, во время передвижения в 3-х метровой зоне» $-2,7 \%$.

Ключевые слова: теннис настольный; координационные способности; упражнения с мячами; упражнения с ракеткой.

Помещикова, І., Асєєва, Я., Чуча, Ю. (2021), «Вплив вправ 3 м'ячем на координаційні здібності юних спортсменів 8-9 років, які займаються тенісом настільним» doi:10.15391/snsv.2021-1.010 


\begin{abstract}
Irina Pomeshchikova, Yaroslavna Aseieva, Yuri Chucha. Influence of exercises with a ball on coordination abilities of 8-9-year-old young sportsmen, engaged in table tennis. Purpose: to develop approaches to improve the coordination abilities of young sportsmen in table tennis under the influence of specially selected exercises with a tennis ball. Material and methods: two groups of young pupils at the age of 8-9 years in the total number of 24 persons (control group, $n=12$, experimental group, $n=$ 12) of the children's and youth sports school No. 11 in Kharkov took part in the research. The tests recommended by the curriculum for children's and youth table tennis sports schools were used to determine the indicators of coordination abilities. The pedagogical experiment lasted 3 months and consisted of the introduction into practice of the experimental group of specially selected exercises. Results of introducing exercises with tennis balls aimed at developing coordination abilities into the educational and training process of the experimental group of 8-9-year-old pupils in table tennis, a reliable improvement in the indicators of test exercises were revealed: in hitting a tennis ball on a racket for 1 minute, on the inside and the outside of the racket and alternating the side of the racket, run sideways around the table, running on the eight $(p<0,05)$. No probable difference was found in tests: tossing and catching a tennis ball with two hands in 30s, transfer balls while moving in a 3-meter zone, $(p>0,05)$. Conclusions: the improvement of manifestations of coordination abilities in 8-9-year-old children of the experimental group who are engaged in table tennis, after the introduction of the specially selected exercise system into the training process, amounted to: in the test «Hitting a tennis ball on a racket for 1 minute on the inside» - 25,3\%, «Hitting a tennis ball on a racket for 1 minute on the outside of the racket»-27,3\%, «Hitting a tennis ball on a racket for 1 minute on the inside and the outside of the racket in turn»-39,0\%, "Tossing and catching a tennis ball with two hands no higher than the head in 30 s $-5,5 \%$, «Run sideways around the table» - 5, $8 \%$, «Running in the eight»-2,5\%, "Transfer of balls while moving in a 3-meter zone»-2,7\%.
\end{abstract}

Keywords: table tennis; coordination capacities; exercises with balls; exercises with a racket.

\title{
References
}

1. Asjejeva, Ja. \& Shevchenko, O. (2019), «Vzajemozv'jazok psyhofiziologichnyh pokaznykiv ta tehnichnoi' pidgotovlenosti u sportsmeniv z nastil'nogo tenisu na etapi poperedn'oi' bazovoi' pidgotovky", Slobozhans'kyj naukovo-sportyvnyj visnyk, No. 6K, pp. 5-9. DOI:10.15391/snsv.2019-6.021. (in Ukr.)

2. Globa, T.A. (2015), «Nastil'nyj tenis jak zasib rozvytku koordynacijnyh zdibnostej studentiv u procesi zanjat' fizychnym vyhovannjam», Pedagogika formuvannja tvorchoi' osobystosti u vyshhij i zagal'noosvitnij shkolah, No. 42, pp. 87-93. (in Ukr.)

3. Drobysh, A.S. (2016), «Metodika razvitija koordinacionnyh sposobnostej u sportsmenov 10-12 let, zanimajushhihsja nastol'nym tennisom», Turizm i obrazovanie: issledovanija i proekty: materialy Vserossijskoj, T. 24, pp. 186-189. (in Russ.)

4. Kozetok, I. (2001), «Formuvannja struktury vzajemozv’jazkiv ruhovyh jakostej i koordynacijnyh zdibnostej u ditej molodshogo shkil'nogo viku», Teorija i metodyka fizychnogo vyhovannja i sportu, No. 1, pp. 41-45. (in Ukr.)

5. Kolomijceva, O., Radchenko, Ja. (2012), «Nastil'nyj tenis jak zasib rozvytku koordynacijnyh zdibnostej studentiv koledzhu», Slobozhans'kyj naukovo-sportyvnyj visnyk, No. 5-1 (32), pp. 16-19. (in Ukr.)

6. Kostenko, E.G. \& Lysenko, V.V. (2020), «Obrabotka metodologicheskih dannyh vospitanie lovkosti u detej», E-Scio, No. (9 (48)), pp. 669-674. (in Russ.)

7. Malenjuk, T.V. \& Brojakovs'kyj, O.V. (2020), «Udoskonalennja zagal'noi' fizychnoi' pidgotovlenosti studentiv na zanjattjah pidvyshhennja sportyvnoi' majsternosti z nastil'nogo tenisu», Problemy ta perspektyvy rozvytku fizychnogo vyhovannja, sportu i zdorov'ja ljudyny : materialy V Vseukr. nauk.-prakt. konf. (23-24 kvitnja 2020 r.), Poltava : Simon, pp. pp. 46-52. (in Ukr.)

8. Nastil'nyj tenis. Navchal'na programa dlja dytjacho-junac'kyh sportyvnyh shkil, specializovanyh dytjacho-junac'kyh shkil olimpijs'kogo rezervu, shkil vyshhoi' sportyvnoi' majsternosti, ta specializovanyh navchal'nyh zakladiv sportyvnogo profilju / uklad. Gryshko, L.G., Gryshko, Ju.Ju. \& Ibraimova, M.V. Kyi'v, 2013, 137 p. (in Ukr.)

9. Okopnyj, A. (2012), «Vykorystannja tehnichnyh zasobiv navchannja dlja zabezpechennja tochnosti ruhiv gravciv u nastil'nyj tenis», Moloda sportyvna nauka, HI Mizhnar. nauk.-metod. konf. Donec'k, pp. 17-21. (in Ukr.)

10. Pomeshhykova, I., Chucha, N., Chucha, Ju. \& Kudimova, O. (2020). «Zminy pokaznykiv koordynacijnyh zdibnostej basketbolistiv students'koi' komandy pid vplyvom special'no pidibranyh vprav z m'jachamy», Sportyvni igry, No. 2 (16), pp. 58-68. https://doi: 10.15391/ si.2020-2.06. (in Ukr.)

11. Pomeshhykova, I.P. \& Pashhenko, N.O. (2016), "Stan koordynacijnyh zdibnostej basketbolistiv studens'koi' komandy», Materialy XVI Mizhnarodnoi' naukovo-praktychnoi' konferencii' "Fizychna kul'tura, sport ta zdo-rov'ja: stan, problemy ta per-spektyvy" (Harkiv, gruden' 2016 r.), pp. 193-196. (in Ukr.)

12. Pomeshhykova, I.P., Pashhenko, N.O., Shyrjajeva, I.V. \& Kudimova, O.V. (2021), «Zminy pokaznykiv rivnovagy basketbolistiv 12 rokiv pid vplyvom vprav na balansuval'nij pivsferi», Sportyvni igry, No. 2 (20), pp. 83-91. https://doi: 10.15391/si.2021-2.08. (in Ukr.)

13. Prijmakov, A.A. \& Kozetok, I.I. (2000), «Zakonomernosti razvitija koordinacionnyh dvizhenij u detej 7-9 let», Nauka v olimpijskom sporte, No.1, pp. 53-59. (in Russ.)

14. Prokopenko, K.V. (2012), «Harakterystyka vplyvu zasobiv nastil'nogo tenisu na riven' fizychnoi' pidgotovlenosti uchniv molodshyh klasiv», Teormb ta Metodika Fmzičnogo Vihovanni, No. 6, pp. 35-39. (in Ukr.)

15. Fajchak, Roman, Popel', Sergij \& Fajchak, Ivan (2013), «Rozvytok koordynacijnyh zdibnostej u sportsmeniv, shho zajmajut'sja nastil'nym tenisom», Moloda sportyvna nauka Ukrai'ny, T.1, pp. 266-269. (in Ukr.)

16. Hudec, R.K. (2005), Nastol'nyj tennis. Tehnika s Vladimirom Samsonovym M.: VistaSport. 272 p. (in Russ.)

17. Chernjaev, A.A. \& Pajkov, M.B. (2018), «Metodika sovershenstvovanija koordinacionnyh sposobnostej u tennisistov 11-12 let v podgotovitel'nom periode», Sovremennye problemy nauki i obrazovanija, No. 6, pp. 225-225. (in Russ.)

18. Shevchenko, O.O. \& Asejeva Ja.F. (2018), «Kontrol' rivnja special'noi' fizychnoi' pidgotovlenosti sportsmeniv v grupi bazovoi' pidgotovky tenisu nastil'nogo", Sportyvni igry, No. 4, pp. 60-66. (in Ukr.)

19. Shyjan, V.M. (2013), “Osoblyvosti rozvytku koordynacijnyh zdibnostej badmintonistiv na etapi poperedn'oi' bazovoi' pidgotovky», Slobozhans'kyj naukovo-sportyvnyj visnyk, No. 5, pp. 286-290. (in Ukr.)

20. Bykova, O., Druz, V., Pomeshchikova, I., Strelnikova, E., Strelnikov, G., Melnyk, A. \& Shyriaieva, I. (2017), «Changes in technical preparedness of 13-14-year-old handball players under the influence of coordination orientation exercises", Journal of Physical Education and Sport, T. 17, No. 3, pp. 1899-1905. https://doi:10.7752/jpes.2017.03185

21. Pomeschikova, I., Yevtushenko, A. \& Yevtushenko, I. (2012), «The level of spatial orientation of basketball players aged 14 years», Pedagogics, psychology, medical-biological problems of physical training and sports, No. 3, pp. 106-109. 
22. Pomeshchikova, I.P., Zhang, Xing Yu \& Koval M. (2016), «Level of coordination abilities and physical working capacity of grade 8 female students suzhou wuzhong ying chuu middle school», Education and space (Soul Suzhou China), No. 3, pp. 83-86.

23. Pomeshchikova, I.P., Shevchenko, O.O., Yermakova,T.S., Paievskyi, V.V., Perevoznyk, V.I., Koval, M.V. \& Moiseienko, O.K. (2016), «Influence of exercises and games with ball on coordination abilities of students with disorders of muscular skeletal apparatus», Journal of Physical Education and Sport, No. 16(1), pp. 146-155. https://doi:10.7752/jpes.2016.01024

24. Pomeshchikova, I., lermakov, S., Barti, P., Shevchenko, O., Nosko, M., Yermakova, T. \& Nosko, Y. (2016), «Influence of exercises and games with ball on vestibular stability of students with muscular-skeletal apparatus disorders», Sport Science, No. 9 (1), pp. 75-83.

Received: 27.01.2021.

Published: 22.02.2021.

\section{Відомості про авторів / Information about the Authors}

Помещикова Ірина Петрівна: к. фіз.вих., доцент; Харківська державна академія фізичної культури: вул. Клочківська 99, м. Харків, 61058, Україна.

Помещикова Ирина Петровна: к. физ.восп., доцент; Харьковская государственная академия физической культуры: ул. Клочковская 99, г.Харьков, 61058, Украина.

Irina Pomeshchikova: PhD (Physical education and Sport), assistant professor; Kharkiv State Academy of Physical Culture:Klochkivska str. 99, Kharkiv, 61058, Ukraine.

ORCID.ORG/0000-0003-1343-8127

E-mail: pomeshikovaip@ukr.net

Асєєва Ярославна Федірівна: Харківська державна академія фізичної культури: вул. Клочківська, 99. м. Харків, 61058, Україна.

Асеева Ярославна Федоровна: Харьковская государственная академия физической культуры: ул. Клочковская, 99.

Yaroslavna Aseieva: Kharkiv State Academy of Physical Culture: Klochkivska str. 99, Kharkiv, 61058, Ukraine.

ORCID.ORG/0000-0003-0423-7788

E-mail: 31031975@ukr.net

Чуча Юрій Іванович: доцент; Харківська державна академія фізичної культури: вул. Клочківська 99, м. Харків, 61058, україна.

Чуча Юрий Іванович: доцент; Харьковская государственная академия физической культуры: ул. Клочковская 99, г. Харьков, 61058, Украина.

Yuri Chucha: assistant professor; Kharkiv State Academy of Physical Culture:Klochkivska str. 99, Kharkiv, 61058, Ukraine.

ORCID.ORG/0000-0002-7563-6359

E-mail: chychayi@ukr.net 